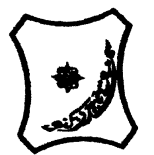

Bayero Journal of Pure and Applied Sciences, 10(1): 312 - 314

Received: May, 2016

Accepted: January, 2017

ISSN $2006-6996$

\title{
PHYSICO-CHEMICAL EVALUATION OF WASTEWATER IN KATSINA METROPOLIS, KATSINA NIGERIA
}

\author{
${ }^{* 1}$ Abba, A., ${ }^{2}$ Ibrahim, S., and ${ }^{3}$ Ugya, A. Y. \\ ${ }^{* 1}$ Department of Biological Sciences Federal University Lokoja, Kogi state \\ 2,3 Department of Applied Biology, Bayero University Kano \\ *Correspondence author: abdin2007@gmail.com
}

\section{ABSTRACT}

The study was designed to assess the physico-chemical parameters of wastewater at Katsina metropolis from June-August, 2015. Water samples were collected twice in a month at three (3) sampling sites designated as K/Marusa, K/Durbi and K/Sauri and was analyzed for surface water temperature, $p^{H}$, dissolved oxygen (DO), biochemical oxygen demand (BOD) and turbidity. These parameters were compared with their sampling sites in which a significant difference was observed $(P<0.05)$. The water is well oxygenated and alkaline in all locations (7.7,7.9 and 7.67), temperature were relatively high $\left(26 \mathrm{C}, 25.7 \mathrm{C}\right.$ and $\left.25.8^{\circ} \mathrm{C}\right)$, DO mean values were $4.6,3.9$ and 4.8 while BOD were 2.6, 2.53 and 2.53. Turbidity values were 11.5, 15.8 and 11.2. Therefore, measure should be put in place to regulate improper refuse disposal into the wastewater and a possible creation of wastewater treatment plant so as to avoid adverse conditions.

Keywords: Physico-chemical Parameters, Pollution, Wastewater, and Katsina Metropolis

\section{INTRODUCTION}

Increase of urban populations and increased coverage of domestic water supply and sewage give rise to greater quantities of urban waste water. On the contrary, providing safe and sufficient drinking water and proper sewerage system remains as the challenging tasks for many developing countries particularly so, in urban areas. The major challenge is to optimize the benefits of wastewater as a resource for the water and the nutrients it contains, and to minimize the negative impacts of its use on human health. Urban wastewater means domestic waste water, consisting of black water excreta, urine and associated sludge and grey water kitchen and bathroom wastewater or the mixture of domestic wastewater from commercial establishments and institutions including hospitals with industrial wastewater and run-off rain water(Van der hook, 2004). According to 1985 reports, ground water contamination is increasing due to anthropogenic activities like disposal of waste, sewage, industrial waste, (APHA, 1985). Due to rapid industrialization, urbanization, overexploitation of ground water and improper wastewater techniques, results in contamination of ground water in urban areas (Yadav and Singh, 2009). There is a need to know the state of pollutant in wastewater in Katsina metropolis; this is because most of the vegetables consumed in the area were irrigated by the use of wastewater which harbors different forms of microbial flora that alters the physic-chemical parameters of the wastewater. Therefore, pollution of water resources needs a serious and immediate attention through periodical checkup of water quality.

\section{MATERIALS AND METHODS}

\section{Study Area}

The study area is Katsina metropolis, located at latitude $12^{\circ} 15 \mathrm{~N}$ and longitude $7^{\circ} 30 \mathrm{E}$ the capital city of Katsina state.

Katsina is located some $257 \mathrm{~km}$ east of the city of Sokoto, and $135 \mathrm{~km}$ northwest of Kano, close to the border with Niger. Its population is approximately $5,801,584$ (NPC, 2006) and it accounts for $4.1 \%$ of Nigeria's total population.

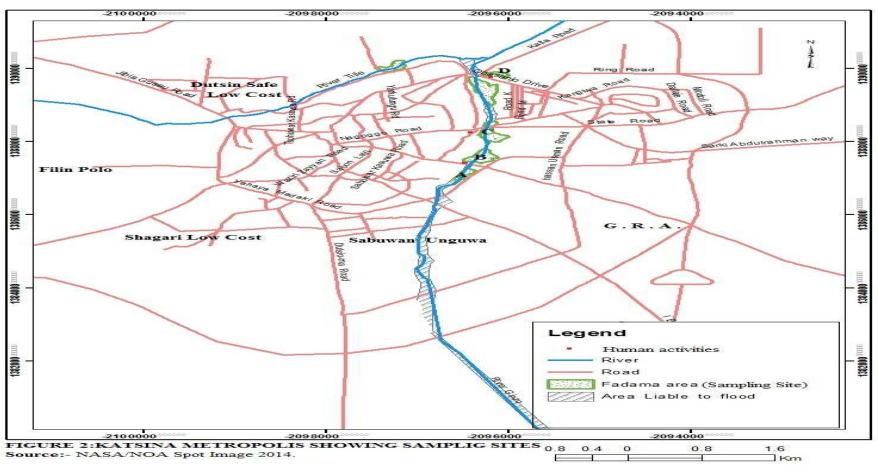

FIGURE 1: KATSINA METROPOLIS SHOWING SAMPLING SITES (Source: NASA/NOA Spot Image 2014) 
Bajopas Volume 10 Number 1 June, 2017 Samlping sites

The sampling sites are K/Durbi, K/Marusa and K/Sauri areas respectively.

K/Marusa:- The area is located on latitude $12^{\circ} 59^{\prime} 19.75^{\prime \prime} \mathrm{N}$ and $7^{\circ} 37^{\prime} 00.87^{\prime \prime} \mathrm{E}$ popularly called Lambun Sarki, and it is the catchment area of Katsina oil mill Ltd and Katsina steel rolling company Ltd.

K/Durbi:- It is located on latitude $12^{\mathbf{0}} 59^{\prime} 44.10^{\prime \prime} \mathrm{N}$ and $\mathbf{7}^{\circ} 37^{\prime} 00.73^{\prime \prime} \mathrm{E}$, the midpoint of the water and irrigational activities takes place.

K/Sauri:- This is located on latitude $13^{\circ} 00^{\prime} 26.92^{\prime \prime} \mathrm{N}$ and $7^{\circ} 36^{\prime} 55.87^{\prime \prime} E$, it's the outlet point of the water. Methodology

Water sampling was carried out from June-August, at each site three samples (3) each were taken, sampling was done twice in a month and measurements were taken between 6:00 -9:00am. Physicochemical parameters including water surface temperature (To), pH, turbidity were directly measured using the HI 98129 Combo pH meter. The content of dissolved oxygen (DO) at each site was assessed with the aid of the DO Meter (YSI55). For the determination of biochemical oxygen demand, $100 \mathrm{ml}$ of water sample were incubated for five days at room temperature $\left(25^{\circ} \mathrm{C}\right)$ in the dark after addition of $2 \mathrm{ml}$ each of manganese chloride solution and Winkler reagent, the resultant precipitate was then dissolved by the addition of $2 \mathrm{ml}$ concentrated $\mathrm{H} 2 \mathrm{SO} 4$. The differences obtained between the initial dissolved oxygen and the final dissolved oxygen concentration obtained after five days at three days. BOD is expressed in milligrams per litre of the sample (APHA, (1985). BODmg-1 = Dissolved oxygen on day Dissolved oxygen on days. BODmg(MgL-1 ) $=x-$ Ymgly

\section{Statistical Analysis}

The analysis of variance (ANOVA) was run to compare the variations in physicochemical parameters of the sampling sites in which a significant difference was observed $P<0.05$.

\section{RESULTS AND DISCUSSION} Significant difference was observed between the the bottom of the water over a period of time (Langland et parameters and duration of collection $(P<0.05)$ using ${ }^{a l .,}$ 2003). analysis of variance ANOVA. The average surface waterer temperature in the study ranges from $25.67 \mathrm{C}$ and $26^{\circ} \mathrm{C}$ (Table 1.0) which is closely related to the one reported by Kolo, 1996 at Shiroro Lake Nigeria and higher than the one reported by Adebisi, 1981, Khan and Ejike 1984, Ovei and Adeniji, 1993. Highest temperature was recorded at $\mathrm{K} /$ Marusa and lowest at K/Durbi and K/Sauri may be attributed to the time lag between the study sites which allows for the warming effect of the solar radiation. The relatively high temperature at $\mathrm{K} / \mathrm{Marusa}$ in June and July were due to dry season experience in the area and a similar effect had been observed in some African inland water bodies (Egborge 1981, Khan and Ejike 1984, Ovei and Adeniji 1993 and Kolo 1996). However, higher $\mathrm{p}^{\mathrm{H}}$ observed at K/Marusa may be as a result of over crowdness of refuse disposal in the area which lead to the decay of organic matter. Frequent dynamic water movement resulted in greater dissolved oxygen (DO) as shown in (Table 1-3). Lower mean value in DO at $\mathrm{K} /$ Durbi and $\mathrm{K} /$ Sauri was due to water depth effect and less disturbance by wind, while at $\mathrm{K} /$ Marusa may be as a result of submerged decaying matters poured by Municipality of the area Porteous (2005). BOD values have been widely most common measures of pollutant organic material in water. It indicates the amount of putrescible organic matter present in water.

Sources of BOD in aquatic environment include leaves and woody debris, dead plants and animals, animal manure, industrial effluents, wastewater treatment plants, feedlots, and food-processing plants, failing septic systems, and urban storm water runoff. According to UN Department of Technical Cooperation for Development the maximum permitted BOD content is < 100 to $300 \mathrm{mg} / \mathrm{L}$. The higher Biological Oxygen Demand (BOD) mean value recorded at $\mathrm{K} /$ Marusa could be due to shallow and submerged woody nature of the site and as a result of high refuse disposal in the area; which lead to the accumulation of decayed organic matter. Therefore, organic matter decaying process used up the dissolved oxygen, thus resulting in lower dissolved oxygen content and high BOD value. Highest turbidity value at K/Durbi (15.83Ntu) is as a result of suspended solids that settle out into the sediment at adopted as a measure of pollution effect. It is one of the

Table 1.0 Average monthly concentration of Phsico-chemical parameters at $\mathrm{K} / \mathrm{marusa}$ area.

\begin{tabular}{lllllll}
\hline $\mathrm{S} / \mathrm{N}$ & Month & $\mathrm{p}^{\mathrm{H}}$ & $\mathrm{Temp}(\mathrm{C})$ & $\mathrm{DO}(\mathrm{g} / \mathrm{mol})$ & $\mathrm{BOD}(\mathrm{g} / \mathrm{mol})$ & Turbidity(Ntu) \\
\hline 1 & June & 8.0 & 25.4 & 4.54 & 2.40 & 11.5 \\
2 & July & 7.6 & 26.1 & 4.65 & 2.68 & 11.5 \\
3 & August & 7.6 & 26.5 & 4.66 & 2.70 & 11.5 \\
& Mean \pm & $\mathbf{7 . 7 3} \pm \mathbf{1 . 0 1}$ & $\mathbf{2 6} \pm \mathbf{0 . 8 3}$ & $\mathbf{4 . 6 1 \pm 0 . 9 1}$ & $\mathbf{2 . 5 9} \pm \mathbf{0 . 3 1}$ & $\mathbf{1 1 . 5} \pm \mathbf{0 . 8 3}$ \\
& SDev. & & & & & \\
\hline
\end{tabular}

Table 2.0 Average monthly concentrations of Phsico-chemical parameters at K/Durbi area.

\begin{tabular}{lllllll}
\hline $\mathrm{S} / \mathrm{N}$ & Month & $\mathrm{P}^{\mathrm{H}}$ & $\mathrm{Temp}(\mathbb{\mathrm { A }} \mathrm{C})$ & $\mathrm{DO}(\mathrm{g} / \mathrm{mol})$ & $\mathrm{BOD}(\mathrm{g} / \mathrm{mol})$ & Turbidity(Ntu) \\
\hline 1 & June & 8.0 & 25.4 & 4.0 & 2.5 & 11.1 \\
2 & July & 8.0 & 26.0 & 3.89 & 2.5 & 15.20 \\
3 & August & 7.7 & 26.0 & 3.89 & 2.6 & 21.20 \\
& Mean \pm & $\mathbf{7 . 9} \pm \mathbf{0 . 1 1}$ & $\mathbf{2 5 . 6 7} \pm \mathbf{0 . 2 1}$ & $\mathbf{3 . 9 3} \pm . \mathbf{3 3}$ & $\mathbf{2 . 5 3} \pm \mathbf{0 . 4 1}$ & $\mathbf{1 5 . 8 3} \pm \mathbf{0 . 2 3}$ \\
& SDev. & & & & & \\
\hline
\end{tabular}


Table 3.0 Average monthly concentrations of Phsico-chemical parameters at K/Sauri area.

\begin{tabular}{|c|c|c|c|c|c|c|}
\hline $\mathrm{S} / \mathrm{N}$ & Month & $\mathrm{p}^{\mathrm{H}}$ & Temp $(\stackrel{0}{O})$ & $\mathrm{DO}(\mathrm{g} / \mathrm{mol})$ & $\mathrm{BOD}(\mathrm{g} / \mathrm{mol})$ & Turbidity(Ntu) \\
\hline 1 & June & 7.6 & 25.4 & 4.5 & 2.4 & 11.5 \\
\hline 2 & July & 7.8 & 26.0 & 4.5 & 2.6 & 10.5 \\
\hline \multirow[t]{2}{*}{3} & August & 7.6 & 26.0 & 4.5 & 2.6 & 11.5 \\
\hline & Mean \pm SDev. & $7.67 \pm 0.12$ & $25.8 \pm 0.83$ & $4.5 \pm 0.41$ & $2.53 \pm 0.33$ & $11.17 \pm 1.01$ \\
\hline
\end{tabular}

\section{CONCLUSION}

From the data obtained in this study, the concentration of physicochemical parameters $\left(\mathrm{p}^{\mathrm{H}}\right.$, temperature, DO, and $\mathrm{BOD}$ ) found in the wastewater were generally within the safe limit set by WHO for wastewater used for irrigational practices.

\section{Acknowledgement}

Authors wish to acknowledge Malam Kabir Yahuza of Department of Microbiology at Umaru Musa Yaradua University for his assistance in this work.

\section{REFERENCES}

Adebisi, A.A. (1981) The Physico-chernical Properties and Hydrology of a Tropical Seasonal RiverUpper Ogun river. Hydrobiologia 79. 157165.

APHA (1985) Standard Methods for the examination of water and wastewater. 18th Edition: American Public Health Association, Washington D.C.

Egborge, $A B$ (1981) Observations of the Vertical distribution of the Zooplankton in the Lake Environmentally responsible waste management. Waste Manag. Vol. 25, pp. 451-459.

Khan, M.A., and Elike, C. (1984) Limnology and Plankton periodicity of los Plateau water reservoir, Nigeria. W. Africa Hydrobiologia 114: 189-199.

Kolo, R.J (1996) The Assessment of Physico-schemical Parameters of Shiroro Lake and its major Tributaries; Hydrobiologia 32:1999-221.

Langland, M., and Cronin, T. (2003) A summary Report of Sediment Process in Cheasapeak

\section{Contributions of Authors}

Ibrahim S. and Abba A. have equal contribution on this paper with A. Y Ugya as least contributor in collecting samples.

\section{Conflict of interest}

Authors declare no conflict of interest on this research article.

Survey. Retrieved from http://pa.water.usgs.gov/reports/wrir034123.pdf

Ovie, S.1., and Adeniji, H.A. (1993) Zooplankton and environmental characteristics of Shiroro Lake at the extremes of its hydrological cycle. Hydrobiologia 286:175-182.

Porteous., A. (2005). Why energy from waste incineration is an essential component of environmentally responsible waste management. Waste Management (New $\begin{array}{lll}\text { York, N. } & \text { Y) 25,451-459 }\end{array}$ doi:10.1016/j.wasman.2005.02.008

Van der Hoek W. (2004) "A Frame Work for a Global Assessment of the Extent of Wastewater Irrigation: The Need for a Common Wastewater Typology, " International Water Management Institute (IWMI), Bierstalpad.

Yadav B. N., and Singh B. N. (2009) Physico-chemical Studies on pollution potential of river Ganga at Kanpur, ACTA Ciencia Indica. 25(C)(2):285-290. 